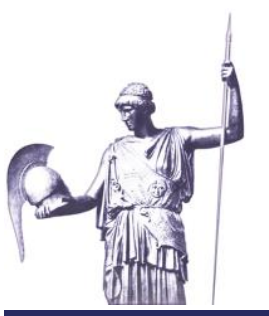

Editorial
Connections: The Quarterly Journal

ISSN 1812-1098, e-ISSN 1812-2973

Sebastian von Münchow, Connections QJ 19, no. 2 (2020): 5-9

https://doi.org/10.11610/Connections.19.2.00

\title{
The Security Impacts of the COVID-19 Pandemic
}

\section{Sebastian von Münchow}

George C. Marshall European Center for International Security Studies, https://www.marshallcenter.org

At the start of March 2020, roughly two months after its outbreak in the Chinese province of Wuhan, COVID 19 hit Western Europe. Up to 5.7 million people around the world have now tested positive, and more than 350000 people have died. In Italy, the United Kingdom, Spain, France, and Germany alone, more than 135000 residents have died. At the beginning of the crisis, European countries and the US sealed off their borders and turned inward to slow down the spread of the virus. Schools, universities, retail, and catering sectors were closed. Wherever possible, office staff were sent home to telework and, in varying intensities, laws and decrees were enacted to enforce physical distancing. At first, domestic themes dominated the headlines. The European public witnessed their respective political decision-makers, along with expert virologists and epidemiologists, discussing which steps were needed to keep the infection rates down and to maintain the safety of health sector employees handling patients. Western liberal democracies particularly were caught in the trilemma of trying to save the lives of its inhabitants, to mind the unprecedented restrictions for its citizens' basic rights, and to ensure economic survival.

Even though COVID-19 caught most international security academics by surprise, the very early days of the lockdown saw little attention being given to the impact of the virus on international relations. Initial papers featured the role of China in the pandemic. Some contributors wondered about Beijing's information politics, while others questioned staged relief operations in Europe. Some authors pinpointed the danger of a hungry China swallowing post-COVID Europe's bankrupt economy, whilst others elaborated on the aggressive rhetoric with which China has attempted to defuse the virus's origin. To a lesser degree, at- 
tention was also paid to Russia, which was trolling Europe's public with disinformation, propagandistic aid campaigns and winkingly promoting authoritarian ways as superior to western models in handling a crisis.

The Garmisch-Partenkirchen-based George C. Marshall European Center for Security Studies, the operational hub of the Partnership for Peace Consortium (PfPC), shared the same fate as most educational institutions in Central Europe. Within days, it halted its operations, canceled courses and trips or delegations attending workshops or seminars abroad. Its staff was sent home to telework, and by the mid- to end of March 2020, professors of the Center's College of International Security Studies had adapted to a new modus operandi. Since then, more than 20 articles have been posted in a distinct COVID-19 section on the Center's website. The majority of contributions came from Marshall Center staff, but also from affiliated writers. Most of the works were written exclusively for the website. A few papers, mostly op-eds, were posted in external outlets and then linked with the Center's site. Based on this freshly generated expertise, College personnel subsequently launched virtual online seminars to discuss, with subject-selected audiences of its 14000 alumni-counting network, different aspects of the coronavirus and international security.

Content-wise, the focus of Marshall Center academics did not differ from the pattern described above. As with their international peers, their early works focused on what is known as Great Power Competition. The posted articles on distancing from China or Putin's role during the pandemic bear witness to these efforts to think about international relations under COVID parameters. A little later, other contributors shed some light on the impact of the virus on specific regions, i.e., the Balkans or Central Asia. Then, writers submitted articles on the legitimate use of tools to control the pandemic in the national domain, namely the use of armed forces or the introduction of legal instruments to decree a lockdown. Other works revisited pre-coronavirus topics such as terrorism or violent extremism and discussed whether COVID-19 urges us to reconsider respective threat assessments. In sum, almost all sections of the Marshall Center security studies' capability were used in considering the effect of the virus on specific fields of expertise.

The College was thankful when the Garmisch-based office of the Partnership for Peace Consortium suggested that some articles could be published in a printed, special edition on "The Security Impacts of the COVID-19 Pandemic." The following selection of ten peer-reviewed contributions is the result. Eight articles are from Marshall Center staffers. By consent of the authors and the College's publication cell, they were decoupled from the above-described endeavor to enrich a worldwide public with analysis on the virus and how it shapes international relations. The works in this volume are grouped in a way that reflects the earlier categorization. They feature a range of international and national security-related topics from Terrorism, Good Governance, Area Studies, and Great Power Competition. 
In the leading article, Dr. Tova Norlen discusses "The Impact of COVID-19 on Salafi-Jihadi Terrorism," ${ }^{1}$ a subject which was less debated when the pandemic spread across the globe in Spring 2020. Perhaps, the domestic health sector focus suppressed the awareness that the jihadi threat would not take a break during the coronavirus-crisis. Dr. Norlen took it upon herself to explain how the current crisis might re-shape the Salafi-Jihadi central message and strategy and, in turn, impact recruitment, tactics, capability, and leadership, and even doctrine.

Professor Ralf Roloff, Deputy Dean of the College of International Security Studies, follows with a contribution entitled "COVID 19 and No One's World: What Impact for the European Union?" ${ }^{2}$ Inter alia, Ralf suggests linking economic support out of the COVID-19 package to democratic values and the protection of civil and human rights and the Rule of Law.

Dr. Pál Dunay continues by elaborating on the European Union. His work "Coronavirus Pandemic and Reactions in the EU Accession Classes of 2004-2007" is a contribution that assembles Area Studies as far as a specific region in Europe is concerned, but also includes elements of Good Governance. ${ }^{3}$ Dr. Dunay explains how Eastern-Central European states have withstood the Coronavirus pandemic of Spring 2020 better than many other countries, but also how governments have struggled for economic recovery and to maintain Rule-of-Law standards.

My article on "The Legal and Legitimate Combat Against COVID-19: German Curfew-related Case Law" digs deeper into the dilemma of how to keep the health sector functioning, to restrict basic freedoms, and to maintain economic and industrial activities. ${ }^{4}$ I shed light on some administrative court decisions in Germany, which had to reconcile these aims.

Former Minister of Defense and today's Head of the Center fo Security and Defense Management at the Bulgarian Academy of Sciences, Dr. Todor Tagarev, a cherished academic and friend of the PfPC and the Marshall Center writes about "Balancing Defense and Civil Support Tasks: The Impact of Covid-19 on the Bulgarian Military's Roles." ${ }^{5} \mathrm{His}$ article can also be seen as a contribution in light

1 Tova Norlen, "The Impact of COVID-19 on Salafi-Jihadi Terrorism," Connections: The Quarterly Journal 19, no. 2 (2020): 11-23, https://doi.org/10.11610/ Connections.19.2.01.

2 Ralf Roloff, "COVID 19 and No One's World: What Impact for the European Union?" Connections: The Quarterly Journal 19, no. 2 (2020): 25-36, https://doi.org/10.11610/Connections.19.2.02.

3 Pál Dunay, "Coronavirus Pandemic and Reactions in the EU Accession Classes of 2004-2007," Connections: The Quarterly Journal 19, no. 2 (2020): 37-47, https://doi.org/10.11610/Connections.19.2.03.

4 Sebastian von Münchow, "The Legal and Legitimate Combat Against COVID-19: German Curfew-related Case Law, "Connections: The Quarterly Journal 19, no. 2 (2020): 49-60, https://doi.org/10.11610/Connections.19.2.04.

5 Todor Tagarev, "Balancing Defense and Civil Support Tasks: The Impact of Covid19 on the Bulgarian Military's Roles," Connections: The Quarterly Journal 19, no. 2 (2020): 61-76, https://doi.org/10.11610/Connections.19.2.05. 
of good governance. While Pal and I featured the domestic toolbox as a critical element in fighting the pandemic, Todor turns to the power instrument of the armed forces and how it can be utilized to mitigate the coronavirus challenge.

Marshall Center professor Jack L. Clarke adds to this interesting aspect with a general article on "Pandemics and Armed Forces: Which Roles are Appropriate?" 6 These publications serve well when comparing authoritarian means to fight the pandemic with those of liberal democracies.

The special edition then continues with three works combining themes of Great Power Competition and Area Studies. Marshall Center faculty member Dr. Petra Weyland's piece on "The Pandemic in the Middle East and North Africa: Reflections on Current and Future Impacts" draws a rather dark forecast for the region in question. ${ }^{7}$

Dr. Greg Gleason from the Garmisch-based College and Professor Kuralay Baizakova (International Relations and World Economy at al-Farabi Kazakh National University, Almaty, Kazakhstan) write about "COVID-19 in the Central Asian Region: National Responses and Regional Implications." ${ }^{8}$ This region is of particular interest since the five states find themselves in the immediate neighborhood of China and Russia. Thus, they are challenged by two revisionist powers seeking political and economic dominance in the region.

Speaking of which, Frank Mouritz, Academic Coordinator for the Master in Security Studies program at the Marshall Center, writes about "Implications of the COVID-19 Pandemic on China's Belt and Road Initiative." ${ }^{9}$ He warns states along the new Silk road to abstain from Beijing's attempts to rebrand its so-called "mask diplomacy" initiative into a "health road" project.

Last but not least, the PfPC's Study Group Regional Stability in South East Europe (SG RSSEE) shares with its readers "The Western Balkan Countries in the Face of the COVID-19 Pandemic: Policy Recommendations." ${ }^{10}$ The recommendations in this article result from the First Virtual RSSEE Meeting held on 28 May 2000. They provide a number of tangible suggestions for Western Balkan gov-

6 Jack L. Clarke, "Pandemics and Armed Forces: Which Roles are Appropriate?" Connections: The Quarterly Journal 19, no. 2 (2020): 77-88, https://doi.org/10.11610/ Connections.19.2.06.

7 Petra Weyland, "The Pandemic in the Middle East and North Africa: Reflections on Current and Future Impacts," Connections: The Quarterly Journal 19, no. 2 (2020): 89-99, https://doi.org/10.11610/Connections.19.2.07.

8 Greg Gleason and Kuralay Baizakova, "COVID-19 in the Central Asian Region: National Responses and Regional Implications," Connections: The Quarterly Journal 19, no. 2 (2020): 101-114, https://doi.org/10.11610/Connections.19.2.08.

9 Frank Mouritz, "Implications of the COVID-19 Pandemic on China's Belt and Road Initiative," Connections: The Quarterly Journal 19, no. 2 (2020): 115-124, https://doi.org/10.11610/Connections.19.2.09.

${ }^{10}$ Study Group Regional Stability in South East Europe, "Policy Recommendations: The Western Balkan Countries in the Face of the COVID-19 Pandemic," Connections: The Quarterly Journal 19, no. 2 (2020): 125-131, https://doi.org/10.11610/ Connections.19.2.10. 
ernments, as well as for the EU, EU member states and NATO decision-makers on how to confront the coronavirus and security-related challenges in Southeast Europe.

All the articles in this volume were written in the special context of spring/ early summer 2020, the phase when liberal democracies carefully began to reliberalize public life. But restrictions have still endured, impacting on air traffic, trade, in-time production, academic exchange, and others. The articles were submitted when western governments and supra-governmental organizations like the European Union had generated several massive recovery packages. None of the contributions claim that the observations and findings might not be superseded by an eventual second-perhaps even worse-wave of COVID-19 or national political unrest changing a nation's course. Hence, these articles should be read in the historical context of March to May 2020. Nevertheless, the articles do touch upon a salient variety of coronavirus-related aspects in international security studies. This special edition of Connections reveals the early instincts of security studies academics to remember that phenomena like terrorism will not go away due to a pandemic, to generate counter-narratives that shed light on the attempts of authoritarian regimes to discredit western models and to urge our governments to adhere to rule-of-law standards while fighting the virus. In sum, the authors illustrate what ten acknowledged experts considered important and worthy of observation.

The Partnership for Peace Consortium staffers, the editors, reviewers, and authors wish the readers good health and security in reading this special issue on the pandemic and its impact on international affairs.

June 2020

\section{Disclaimer}

The views expressed are solely those of the contributing author and do not represent official views of the PfP Consortium of Defense Academies and Security Studies Institutes, participating organizations, or the Consortium's editors.

\section{Acknowledgment}

Connections: The Quarterly Journal, Vol. 19, 2020 is supported by the United States government.

\section{About the Author}

Sebastian von Münchow - see the CV on p. 60 of this issue, https://doi.org/ 10.11610/Connections.19.2.04. 